\title{
Post-settlement Life Cycle Migration Patterns and Habitat Preference of Coral Reef Fish that use Seagrass and Mangrove Habitats as Nurseries
}

\author{
E. Cocheret de la Morinière ${ }^{a}$, B. J. A. Pollux ${ }^{a}$, I. Nagelkerken ${ }^{a}$ and \\ G. van der Velde ${ }^{a, b}$ \\ ${ }^{a}$ Department of Animal Ecology and Ecophysiology, University of Nijmegen, Toernooiveld 1, 6525 ED Nijmegen, \\ The Netherlands
}

Received 14 May 2001 and accepted in revised form 8 October 2001

\begin{abstract}
Mangroves and seagrass beds have received considerable attention as nurseries for reef fish, but comparisons have often been made with different methodologies. Thus, relative importance of different habitats to specific size-classes of reef fish species remains unclear. In this study, 35 transects in 11 sites of mangroves, seagrass beds and coral reef were surveyed daily, in and in front of a marine bay on the island of Curaçao (Netherlands Antilles). The density and size-frequency of nine reef fish species (including herbivores, zoobenthivores and piscivores) was determined during a five-month period using a single methodology, viz. underwater visual census. All species were 'nursery species' in terms of their high densities of juveniles in mangroves or seagrass beds. Relative density distribution of the size-classes of the selected species over mangroves and seagrass beds suggested high levels of preference for either mangroves or seagrass beds of some species, while other species used both habitats as a nursery. Spatial size distribution of the nine species suggested three possible models for Post-settlement Life Cycle Migrations (PLCM). Haemulon sciurus, Lutjanus griseus, L. apodus, and Acanthurus chirurgus appear to settle and grow up in bay habitats such as mangroves and seagrass beds, and in a later stage migrate to the coral reef (Long Distance PLCM). Juveniles of Acanthurus bahianus and Scarus taeniopterus were found only in bay habitats at close proximity to the coral reef or on the reef itself, and their migration pattern concerns a limited spatial scale (Short Distance PLCM). Some congeneric species carry out either Long Distance PLCM or Short Distance PLCM, thereby temporarily alleviating competition in reef habitats. Haemulon flavolineatum, Ocyurus chrysurus and Scarus iserti displayed a Stepwise PLCM pattern in which smallest juveniles dwell in the mouth of the bay, larger individuals then move to habitats deeper into the bay, where they grow up to a (sub-) adult size at which they migrate to nearby coral reef habitats. This type of stepwise migration in opposite directions, combined with different preference for either mangroves or seagrass beds among (size-classes of) species, shows that reef fish using in-bay habitats during post-settlement life stages may do so by choice and not merely because of stochastic dispersal of their larvae, and underline the necessity of these habitats to Caribbean coral reef systems.

(C) 2002 Elsevier Science Ltd. All rights reserved.
\end{abstract}

Keywords: fish; nursery grounds; mangrove swamps; seagrass; coral reef; Caribbean Sea; migration; Curaçao

\section{Introduction}

In many studies, juveniles of reef fish species were found in high densities in non-reef habitats, while the adults were found almost exclusively on the coral reef itself (Pollard, 1984; Parrish, 1989). From this spatially heterogeneous size-frequency distribution, Post-settlement Life Cycle Migration (PLCM) patterns were suggested that gave birth to the nursery concept. Mangroves and seagrass beds are considered nurseries to some reef fish species in the Western Atlantic, Indian Ocean and Pacific Ocean (Pollard, 1984; Parrish, 1989). Several authors have suggested the benefits of nurseries to juvenile reef fish, varying from high food availability to lower predation

${ }^{b}$ Corresponding author. E-mail: gerardv@sci.kun.nl efficiency, lower predator abundance, and high interception rate of the vegetation to planktonic larvae (Odum \& Heald, 1972; Carr \& Adams, 1973; Ogden \& Ziemann, 1977; Blaber \& Blaber, 1980; Shulman, 1985; Parrish, 1989; Heck \& Crowder, 1991; Robertson \& Blaber, 1992).

Most authors, however, have focused on one or two habitats of the mangrove-seagrass-reef continuum, often with different sampling methods, thus complicating comparisons among studies and among habitats (e.g. Robertson \& Duke, 1987; Thayer et al., 1987; Yáñez-Arancibia et al., 1988; Blaber et al., 1989; Baelde, 1990; Rooker \& Dennis, 1991; Sedberry \& Carter, 1993; Laegdsgaard \& Johnson, 2001). Quantitative data on ontogenetic shifts in habitat use from nursery to adult reef association are 
largely lacking (Ogden \& Ehrlich, 1977; Weinstein \& Heck, 1979; Rooker \& Dennis, 1991; Appeldoorn et al., 1997; Nagelkerken et al., 2000a) and the relative importance of these nurseries to different size-classes of reef fish species is still poorly known (Ogden \& Gladfelter, 1983; Birkeland, 1985).

In recent underwater visual surveys in seven different habitats in a marine island bay in Curaçao (Netherlands Antilles), a number of reef fish species of which juveniles were highly abundant in bay environments were identified and grouped as 'nursery species' (Nagelkerken et al., 2000a). Nagelkerken et al. $(2000 a)$ used a low frequency of surveys in a large number of transects, and focused on fish community structure in a range of habitats (mangroves, seagrass beds, algal beds, channel, fossil reef terrace notches, boulders, coral reef). Of all habitats in that study, seagrass meadows proved to contain highest total numbers of fish, calculated from observed density and total surface area.

In the same clear water marine bay in the Caribbean, a selection of seven ' nursery species' of which juvenile individuals had been found in large numbers in mangroves and seagrass beds was studied in detail (Acanthurus chirurgus, Haemulon flavolineatum, H. sciurus, Lutjanus apodus, L. griseus, Ocyurus chrysurus, and Scarus iserti). In addition to this set of herbivorous, zoobenthivorous and piscivorous fish, two congeneric species were selected that were encountered in significant quantities in some seagrass beds near the adjacent fringing reef (Scarus taeniopterus and Acanthurus bahianus). Using daytime underwater visual census as a single method to quantify the abundance of the nine selected species and estimate their size, heterogeneity of the spatial size-frequency distribution of these fish species in reef habitats, mangroves and seagrass meadows was tested. In this way, association of specific size-classes of reef fish with specific habitats or spatially separated sites provides information from which Post-settlement Life Cycle Migration (PLCM) patterns can be derived, taking day-to-day variation over a five month period into account. Additionally, differences in spatial distribution and habitat preference can be compared among species.

The questions that will be addressed are:

1. Do size-classes of the selected species display any preference for mangrove or seagrass habitats in terms of densities?

2. Do habitats differ in the size-structure of the subpopulations that they harbour?

3. Which spatial migration patterns can be inferred from average densities and sizes by comparison of the subpopulations at the various sites?

\section{Methods}

\section{Study area}

The present study was carried out in Spanish Water Bay in Curaçao, Netherlands Antilles (Figure 1). This $3 \mathrm{~km}^{2}$ bay is shallow (largely $<6 \mathrm{~m}$ deep), harbours extensive seagrass meadows and is fringed by mangroves (Rhizophora mangle). Water depths under mangrove canopies ranged between $0.8 \mathrm{~m}$ and $1.8 \mathrm{~m}$. These canopies provide dark habitats (average light extinction underwater was $85 \%$, as opposed to $40 \%$ over seagrass beds). The seagrass beds are dominated by monospecific stands of Thalassia testudinum (Kuenen \& Debrot, 1995). Mean shoot density $( \pm \mathrm{SD})$ in the seagrass transects was $246 \mathrm{~m}^{2}( \pm 110)$ and seagrass canopy height averaged $28.0 \mathrm{~cm}$ $( \pm 11 \cdot 5)$.

There is no freshwater input into the bay other than rain, and salinity (avg. 35.4) is slightly higher than on the reef (avg. 34.6). Bay water temperature averaged $30 \cdot 1{ }^{\circ} \mathrm{C}( \pm 0 \cdot 8)$, while water temperature on the reef averaged $28.4{ }^{\circ} \mathrm{C}( \pm 0 \cdot 9)$. Visibility was high at all sites, and varied between an average of $6.5 \mathrm{~m}( \pm 1 \cdot 8)$ in the bay and $21.4 \mathrm{~m}( \pm 3 \cdot 1)$ on the reef as measured by means of a horizontal Secchi disk. The average tidal amplitude in the area is $30 \mathrm{~cm}$ (De Haan \& Zaneveld, 1959).

The bay has a long $(1 \mathrm{~km})$ and narrow $( \pm 70 \mathrm{~m})$ entrance that connects it to the adjacent fringing reef. This reef is part of a marine park that stretches up to the southwest tip of the island. The reef system starts with a shallow reef flat (from $2-7 \mathrm{~m}$ depth), typically covered by gorgonians, at the edge of which the drop-off is located (at $5-10 \mathrm{~m}$ depth). Coral cover on the drop-off and reef wall is predominated by the stony coral Montastrea annularis. A detailed description of the reefs in the Netherlands Antilles can be found in Bak (1975).

\section{Sampling design}

A total of 35 permanent transects were used in 11 sites on the reef and in the bay (Table 1), covering a total area of about $4500 \mathrm{~m}^{2}$. Each of the transects was censused 29 times on average, during daytime in May through to September 1998. In Spanish Water Bay, six seagrass sites were selected (Figure 1). At each seagrass site, three permanent 3 by $50 \mathrm{~m}$ belt transects were placed, which were surveyed by snorkelling. Average water depth of these transects was between 0.8 and $2.4 \mathrm{~m}$. Adjacent to four of the seagrass sites (numbered 2, 3, 4 and 6) was a mangrove site (Figure 1). The mangrove stands consist of strips of vegetation 


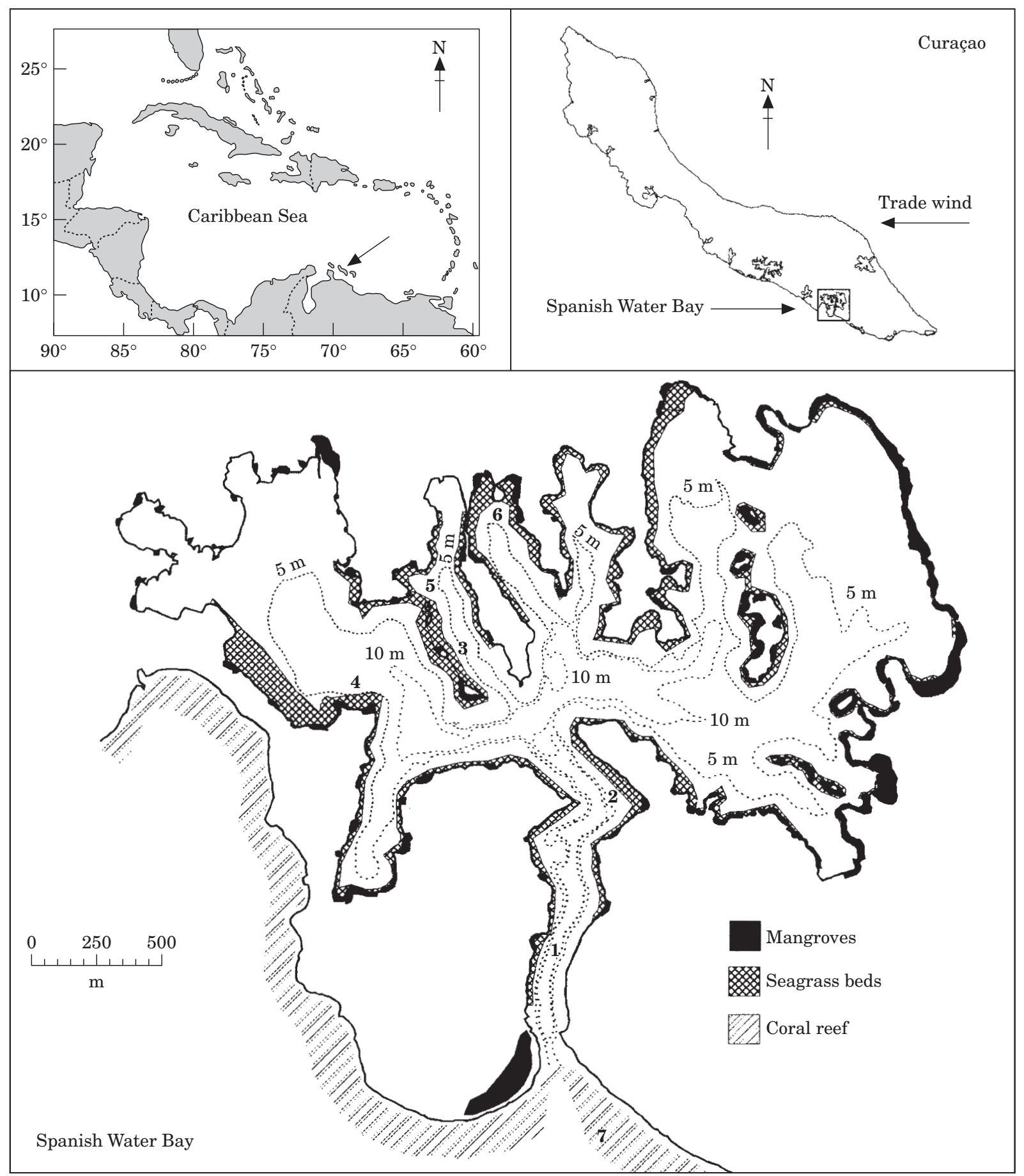

Figure 1. Location of the study sites in Spanish Water Bay. At sites 1-6 the seagrass beds were censused, while at site 2, 3, 4 , and 6 mangroves were also surveyed. Site 7 was the reef site.

hanging over from fossil reef ledges, hence providing structural complexity from prop roots or branches in the water column beneath the mangrove canopy. The eight mangrove transects were narrow underwater habitats, and were censused by snorkelers. In the mangroves, transect width was between $1 \cdot 1$ and $2 \cdot 1 \mathrm{~m}$
(Table 1). At the reef site (numbered 7, Figure 1), three permanent 3 by $50 \mathrm{~m}$ belt transects were placed at three depths $(5,10$ and $15 \mathrm{~m})$ parallel to the coastline, using nylon twine. The three $5 \mathrm{~m}$ deep transects were placed where the sandy reef flat ends at the start of the drop-off, the three $10 \mathrm{~m}$ deep transects 
TABLE 1. Surface area of the 35 transects in all sites and habitats. Site numbers correspond to Figure 1. On the coral reef, 3 transects were used at each depth, as indicated between brackets

\begin{tabular}{|c|c|c|c|c|c|}
\hline Site & Habitat & Transect & $\begin{array}{l}\text { Width } \\
\text { (m) }\end{array}$ & $\begin{array}{l}\text { Length } \\
\text { (m) }\end{array}$ & $\begin{array}{l}\text { Area } \\
\left(\mathrm{m}^{2}\right)\end{array}$ \\
\hline $1-6$ & Seagrass & $\begin{array}{l}1 \\
2 \\
3\end{array}$ & $\begin{array}{l}3 \cdot 0 \\
3 \cdot 0 \\
3 \cdot 0\end{array}$ & $\begin{array}{l}50 \cdot 0 \\
50 \cdot 0 \\
50 \cdot 0\end{array}$ & $\begin{array}{l}150 \cdot 0 \\
150 \cdot 0 \\
150 \cdot 0\end{array}$ \\
\hline 2 & Mangrove & $\begin{array}{l}1 \\
2\end{array}$ & $\begin{array}{l}1 \cdot 3 \\
1 \cdot 3\end{array}$ & $\begin{array}{l}37 \cdot 5 \\
40 \cdot 0\end{array}$ & $\begin{array}{l}48 \cdot 8 \\
52 \cdot 0\end{array}$ \\
\hline 3 & & 1 & $1 \cdot 1$ & $73 \cdot 0$ & $80 \cdot 3$ \\
\hline 4 & & $\begin{array}{l}1 \\
2\end{array}$ & $\begin{array}{l}1 \cdot 4 \\
1 \cdot 3\end{array}$ & $\begin{array}{l}43 \cdot 0 \\
10 \cdot 0\end{array}$ & $\begin{array}{l}60 \cdot 2 \\
13 \cdot 0\end{array}$ \\
\hline 6 & & $\begin{array}{l}1 \\
2 \\
3\end{array}$ & $\begin{array}{l}2 \cdot 1 \\
1 \cdot 4 \\
1 \cdot 5\end{array}$ & $\begin{array}{l}38 \cdot 0 \\
37 \cdot 0 \\
31 \cdot 0\end{array}$ & $\begin{array}{l}79 \cdot 8 \\
51 \cdot 8 \\
46 \cdot 5\end{array}$ \\
\hline 7 & Reef & $\begin{array}{l}1 \text { (3 at } 5 \mathrm{~m} \text { depth) } \\
2 \text { (3 at } 10 \mathrm{~m} \text { depth) } \\
3 \text { (3 at } 15 \mathrm{~m} \text { depth) }\end{array}$ & $\begin{array}{l}3 \cdot 0 \\
3 \cdot 0 \\
3 \cdot 0\end{array}$ & $\begin{array}{l}50 \cdot 0 \\
50 \cdot 0 \\
50 \cdot 0\end{array}$ & $\begin{array}{l}150 \cdot 0 \\
150 \cdot 0 \\
150 \cdot 0\end{array}$ \\
\hline
\end{tabular}

were located on the drop-off whereas the three $15 \mathrm{~m}$ deep transects were situated on the reef slope. At each depth, the three transects were placed $50 \mathrm{~m}$ apart from each other. The depth range was based on a pilot-study that showed that the selected species reached highest densities at depths less than $15 \mathrm{~m}$. Reef sites were censused by Scuba diving.

During visual surveys, individuals of the selected species were counted and their sizes estimated in size-classes of $2.5 \mathrm{~cm}$. Underwater size estimators were trained with objects of known size. The three observers censused all transects using an alternating system so that any bias in size-estimation is equally represented in every transect. The observer effect was tested using ANOVA (see 'Statistical analysis' for further explanation). All juvenile fishes observed in this study were larger than $1 \mathrm{~cm}$ at settlement. Juvenile scarids smaller than $5 \mathrm{~cm}$ (TL) could not be identified in the field. Scarids of sizes smaller than $5 \mathrm{~cm}$ were left out of the data sets of Scarus iserti and $S$. taeniopterus. Juveniles and sub-adults of these two scarids that were larger than $5 \mathrm{~cm}$ (TL) could be distinguished by the characteristics shown in Humann (1996). All other species could be identified at all sizes.

\section{Statistical analysis}

For each species, mean size $(\mathrm{cm})$ and total density $\left(\mathrm{N} 100 \mathrm{~m}^{-2}\right.$ ) of the observed individuals was calculated at each survey of a transect (each of the 35 transects was censused 29 times on average). Data were logtransformed and analysed in a nested ANOVA (GLM, SPSS 8.0) for unequal sample sizes, where sites were nested in habitats and individual surveys of the transects were treated as replicates within sites. Multiple comparisons of means within habitats (among sites) and among habitats were analysed using a Tukey HSD Spjotvoll/Stoline test (Sokal \& Rohlf, 1995). Observer effect was tested by a one-way ANOVA on each of the 35 transects, with observer identity as an independent variable and mean size or total density in the surveys as a dependent variable. None of the 35 ANOVAs on observer effect produced significant differences $(P<0.05)$ in variance among size or density estimation among observers.

Since there is a variety of prevailing habitats in Spanish Water Bay (mangroves, seagrass beds, algal beds, channel, fossil reef terrace notches, boulders, coral reef; see Nagelkerken et al., 2000a), and the selected species use these shallow habitats as daily resting sites to which they return every day after nocturnal migrations to deeper feeding or sleeping grounds (Nagelkerken et al., 2000b), their daytime density distribution can be viewed as a matter of choice. Therefore, the density of a size-class of a fish species in mangroves relative to its density in seagrass beds is viewed as a level of habitat preference. The level of preference for either mangroves or seagrass beds was tested based on densities of the size-classes of each fish species occurring in mangroves and seagrass beds at site numbers 2, 3, 4 and 6 (Figure 1). Only these sites were used for analysis of habitat preference because both seagrass and mangrove habitats were surveyed at those sites. For each sizeclass of each species, the average density in mangroves at a site was divided by the sum density of that size-class in mangroves and seagrass beds at that site. These mangrove-to-seagrass preference levels of the size-classes of the species at the four sites were then clustered using City-block (Manhattan) distances (Statistica for Windows 4.5). In the Manhattan distances measure, the effect of single large differences (outliers) is dampened (in the Euclidean distance measure, differences are squared).

\section{Results}

\section{Habitat preference}

Mean densities $\left(100 \mathrm{~m}^{-2}\right)$ of most species are significantly lower on the coral reef than in seagrass or mangrove habitats, with the exception of Ocyurus chrysurus (coral reef densities similar to densities in seagrass beds and lowest densities in mangroves) and 


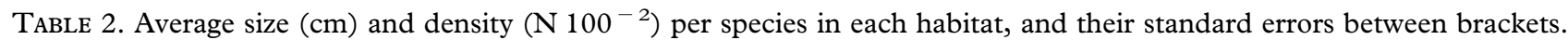
Among sizes, significant $(P<0.05)$ differences are indicated with $a, b$, and $c$ for each species. Among densities, significantly different means are marked $d$, e, or $f$ for each species. Different letters $(a-f)$ mean that averages are significantly different

\begin{tabular}{|c|c|c|c|c|c|c|}
\hline & \multicolumn{3}{|c|}{ Size } & \multicolumn{3}{|c|}{ Densities } \\
\hline & Mangrove & Seagrass & Reef & Mangrove & Seagrass & Reef \\
\hline Acanthurus bahianus & - & $4 \cdot 4^{\mathrm{a}}(0 \cdot 4)$ & $12 \cdot 9^{b}(0 \cdot 6)$ & $0 \cdot 0$ & $4 \cdot 3^{\mathrm{d}}(0 \cdot 5)$ & $4 \cdot 9^{d}(1 \cdot 6)$ \\
\hline Acanthurus chirurgus & $13 \cdot 0^{\mathrm{a}}(0 \cdot 3)$ & $11 \cdot 0^{\mathrm{b}}(0 \cdot 3)$ & $17 \cdot 0^{\mathrm{c}}(0 \cdot 5)$ & $3 \cdot 3^{\mathrm{d}}(0 \cdot 3)$ & $0 \cdot 9^{\mathrm{e}}(0 \cdot 2)$ & $2 \cdot 8^{\mathrm{f}}(0 \cdot 9)$ \\
\hline Haemulon flavolineatum & $8 \cdot 8^{a}(0 \cdot 2)$ & $7 \cdot 7^{\mathrm{b}}(0 \cdot 1)$ & $15 \cdot 1^{\mathrm{c}}(0 \cdot 2)$ & $99 \cdot 8^{\mathrm{d}}(12 \cdot 2)$ & $32 \cdot 1^{\mathrm{e}}(1 \cdot 7)$ & $3 \cdot 2^{\mathrm{f}}(0 \cdot 4)$ \\
\hline Haemulon sciurus & $12 \cdot 3^{\mathrm{a}}(0 \cdot 2)$ & $11 \cdot 5^{\mathrm{b}}(0 \cdot 1)$ & $21 \cdot 5^{c}(0 \cdot 3)$ & $18 \cdot 2^{\mathrm{d}}(1 \cdot 2)$ & $5 \cdot 7^{\mathrm{e}}(0 \cdot 3)$ & $0 \cdot 3^{\mathrm{f}}(0 \cdot 0)$ \\
\hline Lutjanus apodus & $12 \cdot 3^{\mathrm{a}}(0 \cdot 2)$ & $11 \cdot 3^{\mathrm{a}}(0 \cdot 5)$ & $18 \cdot 5^{\mathrm{b}}(0 \cdot 5)$ & $24 \cdot 7^{\mathrm{d}}(1 \cdot 4)$ & $0 \cdot 3^{\mathrm{e}}(0 \cdot 1)$ & $1 \cdot 0^{\mathrm{f}}(0 \cdot 1)$ \\
\hline Lutjanus griseus & $14 \cdot 2^{\mathrm{a}}(0 \cdot 3)$ & $12 \cdot 6^{b}(0 \cdot 3)$ & $16 \cdot 6^{\mathrm{a}}(1 \cdot 1)$ & $8 \cdot 1^{\mathrm{d}}(0 \cdot 8)$ & $0 \cdot 5^{\mathrm{e}}(0 \cdot 1)$ & $0 \cdot 0^{\mathrm{f}}(0 \cdot 0)$ \\
\hline Ocyurus chrysurus & $9 \cdot 3^{\mathrm{a}}(0 \cdot 4)$ & $9 \cdot 8^{\mathrm{a}}(0 \cdot 2)$ & $17 \cdot 1^{\mathrm{b}}(0 \cdot 3)$ & $2 \cdot 1^{\mathrm{d}}(0 \cdot 4)$ & $3 \cdot 6^{\mathrm{e}}(0 \cdot 4)$ & $4 \cdot 1^{\mathrm{e}}(0 \cdot 5)$ \\
\hline Scarus iserti & $8 \cdot 1^{\mathrm{a}}(0 \cdot 3)$ & $7 \cdot 8^{\mathrm{a}}(0 \cdot 1)$ & $11 \cdot 9^{\mathrm{b}}(0 \cdot 3)$ & $11 \cdot 5^{\mathrm{d}}(2 \cdot 0)$ & $13 \cdot 3^{\mathrm{d}}(1 \cdot 3)$ & $2 \cdot 9^{\mathrm{e}}(0 \cdot 2)$ \\
\hline Scarus taeniopterus & $6 \cdot 3^{a}(0 \cdot 0)$ & $6 \cdot 4^{\mathrm{a}}(0 \cdot 1)$ & $16 \cdot 4^{\mathrm{b}}(0 \cdot 3)$ & $6 \cdot 3^{d}(1 \cdot 3)$ & $1 \cdot 7^{\mathrm{e}}(0 \cdot 3)$ & $3 \cdot 6^{\mathrm{f}}(0 \cdot 2)$ \\
\hline
\end{tabular}

Acanthurus bahianus (not observed in mangroves, and seagrass densities not significantly different from reef densities) (Table 2). Overall densities of Scarus iserti, Ocyurus chrysurus, and Acanthurus bahianus are higher in seagrass beds than in mangroves, while the reverse is true for the remaining species (Table 2).

In order to determine the level of habitat preference, mangrove-to-seagrass density ratios (see Statistical analysis) were determined for each size-class at four sites where both mangroves and seagrass beds were surveyed. Cluster analysis of these mangrove-toseagrass density ratios at the four sites (numbered 2, 3 , 4, and 6 in Figure 1) yielded three distinct groups of size-classes of fishes at linkage distance $2 \cdot 0$ (Figure 2). Cluster A had an average mangrove-to-seagrass density ratio of $18 \%$ (range $0-46 \%$ ); in cluster $\mathrm{B}$, that ratio is $60 \%(34-75 \%)$, and in cluster $\mathrm{C}$ it is $93 \%$ (64-100\%). All size-classes of Lutjanus apodus and Haemulon sciurus belonged to cluster $\mathrm{C}$, reflecting a strong preference for mangroves at all size-classes. Lutjanus griseus also seems to prefer mangroves over seagrass beds, since all size-classes were members of cluster $\mathrm{C}$, and one size-class $(7 \cdot 5-10 \mathrm{~cm})$ was in cluster B. Acanthurus bahianus was only observed in seagrass habitats, and therefore all size-classes were members of cluster A. Acanthurus chirurgus distributed itself over mangroves and seagrass beds (most sizeclasses are members of cluster B), with a few individuals of the largest size-class found only in mangroves (and therefore part of cluster C). Ocyurus chrysurus was observed in both seagrass beds and mangroves (size-classes are part of clusters A and B). Scarus iserti occurred mostly in seagrass beds (cluster A), but mangrove preference seems to increase with size (largest sizes in cluster B). Haemulon flavolineatum is represented by size-classes in all three clusters, with ever-larger sizes found in clusters with an increasing mangrove-to-seagrass density ratio. The latter two species suggest that their smallest juveniles are most commonly found in seagrass beds, while mangrove preference increases with size of the juveniles. Only one size-class $(5 \cdot 0-7 \cdot 5 \mathrm{~cm})$ of Scarus taeniopterus was observed in the mouth of the bay, of which individuals were observed in mangroves and seagrass beds (cluster B).

\section{Size-distribution over habitats}

In Figure 3, relative densities of the selected species in the three habitats are depicted for each size-class. All selected species were 'nursery species', in the sense that high densities of juveniles were found in mangroves or seagrass beds, while most adults were observed on the reef. All three habitats differed significantly in the average sizes of individuals of Haemulon flavolineatum, H. sciurus, and Acanthurus chirurgus that they harboured (Table 2). Ocyurus chrysurus, Lutjanus apodus, Scarus iserti, and $S$. taeniopterus showed no difference in average sizes between mangroves and seagrass beds, but individuals on the reef were significantly larger. Acanthurus bahianus was never found in mangroves, and the average size of the individuals of this species observed in seagrass beds was smaller than on the reef. Average size of Lutjanus griseus was significantly smaller in seagrass beds than in mangroves and on the coral reef, while the latter two habitats showed average sizes that were similar to each other. Mean size of all nine species on the reef (Table 2) was always smaller than or corresponded to the approximate mean total lengths at which these species become sexually mature (see Figure 3). 


\section{E. Cocheret de la Morinière et al.}

Linkage distance

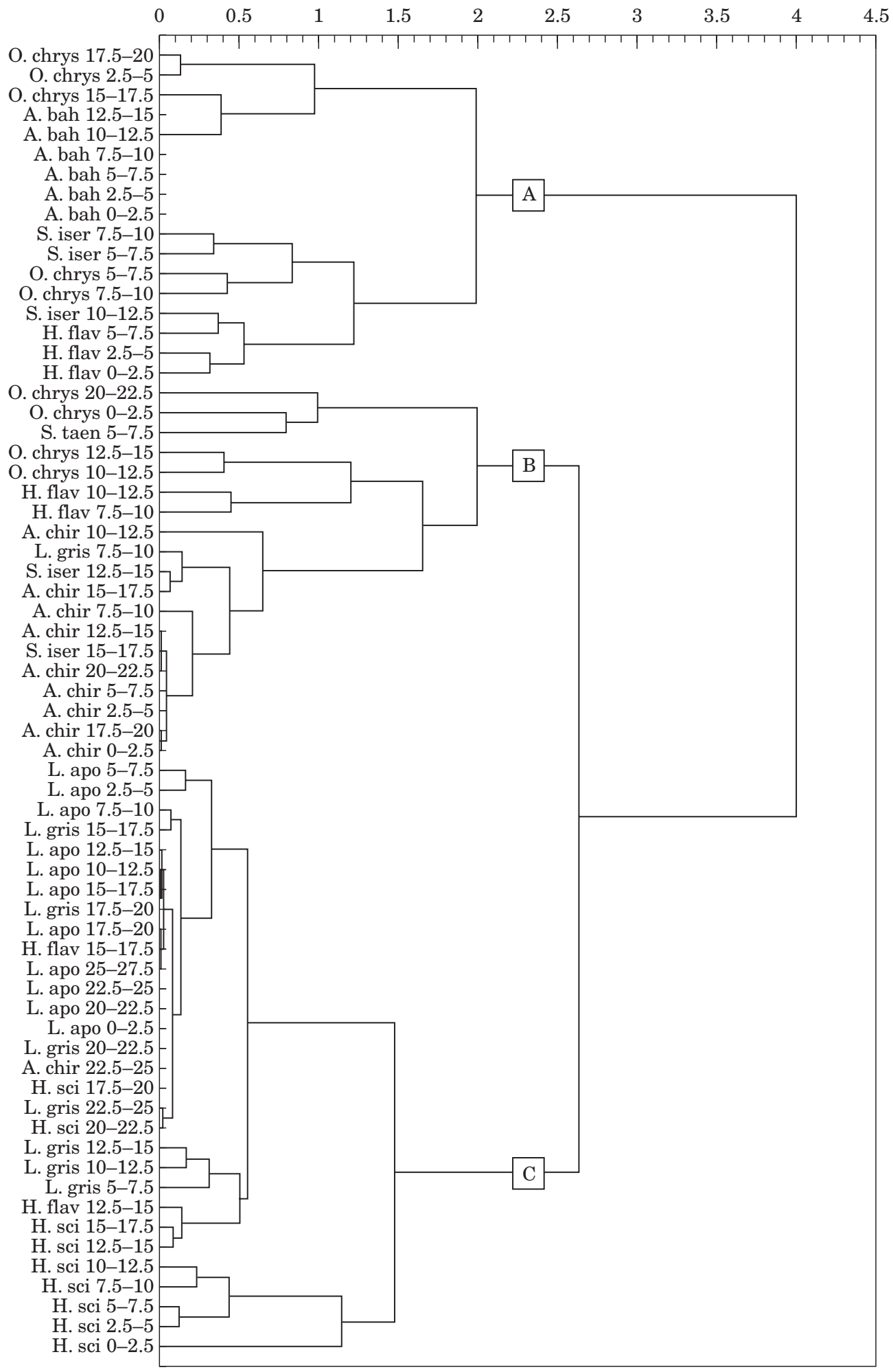

FIGURE 2. Complete linkage of relative (mangrove-to-seagrass) densities of the size-classes of the study species in four sites (numbered 2, 3, 4 and 6; see Figure 1), using City-block (Manhattan) distances. Species are indicated by the following codes: A. $\mathrm{bah}=$ Acanthurus bahianus, A. chir=Acanthurus chirurgus, H. flav=Haemulon flavolineatum, H. sci=Haemulon sciurus, L. apo $=$ Lutjanus apodus, L. gris $=$ Lutjanus griseus, O. chrys $=$ Ocyurus chrysurus, S. iser $=S c a r u s$ iserti, S. taen $=S c a r u s ~ t a e n i-$ opterus. Size-classes $(\mathrm{cm})$ are indicated by the numbers behind the species codes. 


\section{Spatial migration patterns}

The size-frequency distribution of Haemulon flavolineatum, H. sciurus, Acanthurus chirurgus, Lutjanus apodus, Scarus iserti, and Ocyurus chrysurus in mangroves and seagrass beds and on the reef suggests a size-range for each species over which the juveniles start migrating to the coral reef (Figure 3). In the case of Scarus taeniopterus this migration from nursery habitat to coral reef appears to take place rather abruptly, while individuals of Acanthurus bahianus may migrate to reef habitats at all sizes.

When size-frequencies were compared among bay sites within each habitat (ANOVA), heterogeneous distribution patterns over sites emerged for some species (Table 3). For $H$. sciurus, the extremely low $\left(0.09100 \mathrm{~m}^{-2}\right)$ densities of small individuals at site 2 are responsible for significant differences among seagrass sites.

Haemulon flavolineatum, Scarus iserti, and Ocyurus chrysurus displayed a size-frequency distribution in which high densities of small individuals were found in mangroves and seagrass beds in the mouth of the bay (at site numbers 1 and 2, Figure 1), medium-sized fishes deeper in the bay, and large fishes on the reef [Figure 4(a, b and $\mathrm{c})$ ]. This indicates a Postsettlement Life Cycle Migration (PLCM) pattern with two changes of direction.

Both Acanthurus bahianus and Scarus taeniopterus were only encountered at sites 1 and 2 , which are located in the mouth of the bay (see Figure 1), and on the reef. They were not observed at sites located deeper into the bay. In both cases, high densities of small juveniles were detected in the mouth of the bay [Figure 4(d and e)], while statistically lower densities and larger individuals of these species occurred on the reef (Table 2). Their distribution indicates a PLCM pattern that is restricted to seagrass and mangrove sites in the close vicinity of the reef, and does not include temporary residence deeper in the bay.

\section{Discussion}

\section{Habitat preference}

From previous studies in the same bay (Nagelkerken et al., 2000a, b), it is known that fish have a number of occurring habitats to choose from in Spanish Water Bay (mangroves, seagrass beds, algal beds, channel, fossil reef terrace notches, boulders). These shallow habitats are used as daily resting sites, to which the fishes return every day after nocturnal migrations to deeper feeding or sleeping grounds (Nagelkerken et $a l ., 2000 b)$. Therefore, the relative density distribution of a fish species over mangroves and seagrass beds at daytime is considered here as a matter of choice. Cluster-analysis of the mangrove-to-seagrass density ratios of each size-class, at four sites that harboured both habitats showed different levels of habitat preference. Lutjanus apodus and Haemulon sciurus showed strong preference for mangroves over seagrass beds at all size-classes. L. griseus was also strongly associated with mangroves at all size-classes, and moderately by one size-class. Acanthurus bahianus was not observed in mangroves, reflecting strong preference for seagrass beds. Ocyurus chrysurus and Acanthurus chirurgus utilized both habitats. Scarus iserti and Haemulon flavolineatum also used both habitats, but there was a trend of increased preference for mangroves with increasing fish size, while the smallest juveniles of these species were highly associated with seagrass beds. Though seemingly marginal habitats, strips of mangroves of no more than 1 by $40 \mathrm{~m}$ at times may contain hundreds of individuals in resting schools. The preference of Scarus taeniopterus for mangroves may be exaggerated (mangrove-to-seagrass density ratio was about $60 \%: 40 \%$ ), since juveniles smaller than $5 \mathrm{~cm}$ were excluded from the data set. Unidentifiable scarid juveniles of this size were mostly found in the mouth of the bay (average density $38.2100 \mathrm{~m}^{-2}$ in the mouth of the bay as opposed to $0.8100 \mathrm{~m}^{-2}$ in transects deeper in the bay) in seagrass beds. Nagelkerken et al. $(2000 a, c)$ have found similar overall density distributions of these species in mangrove habitats and seagrass habitats in Curaçao and Bonaire. The level of preference of these fish species for mangroves or seagrass beds in the situation where both habitats occur, however, is no indication of the level of dependence on these habitats. From comparisons among bays with and without mangroves or seagrass beds (Nagelkerken et al., 2001), it is known that species that showed strong preference for mangroves in the present study (Lutjanus apodus, L. griseus, Haemulon sciurus) depend largely on the presence or absence of seagrass beds. Given the choice, such species apparently prefer mangroves as daytime resting sites for shelter, while their dependence on seagrass beds is best explained by the larger abundance of food in seagrass habitats in which they forage at night.

\section{Size-distribution and spatial migration patterns}

All selected species proved to be ' nursery species' in the sense that juveniles were much more abundant in mangroves or seagrass beds than on the reef, as expected from our previous study (Nagelkerken et al., 2000a). Of nine species, six (Haemulon flavolineatum, 
(a) H. flavolineatum

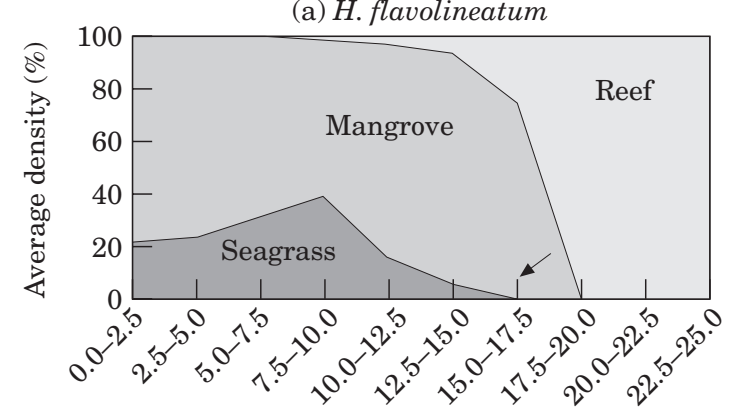

(c) A. chirurgus

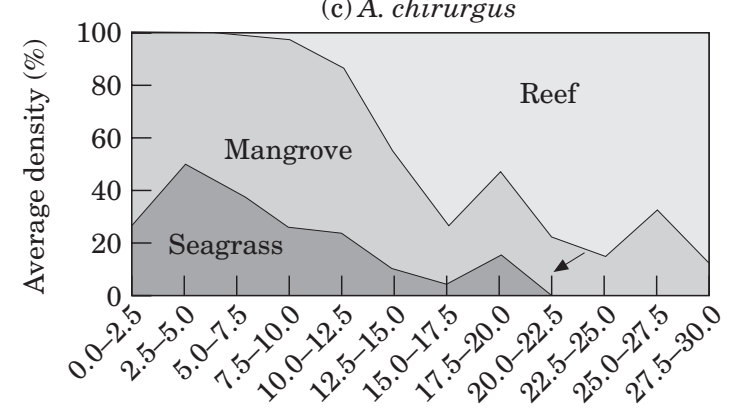

(e) L. apodus

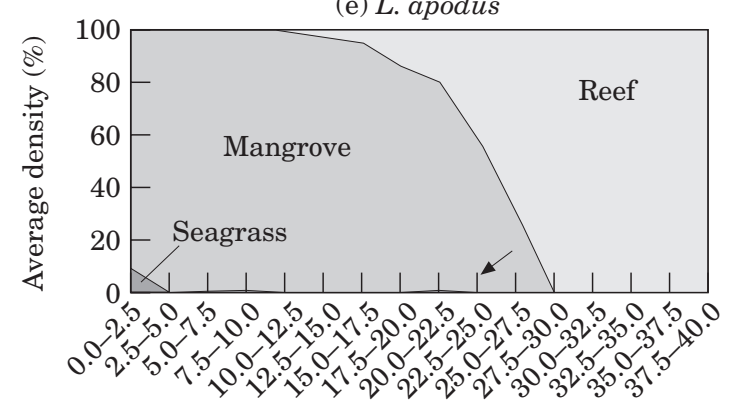

(g) Scarus iserti

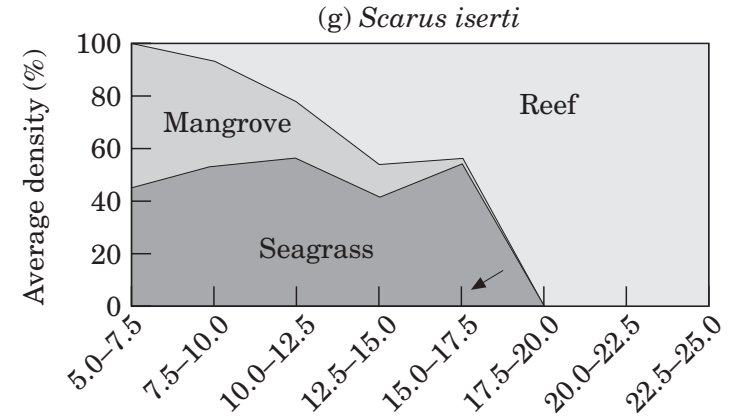

(i) A. bahianus

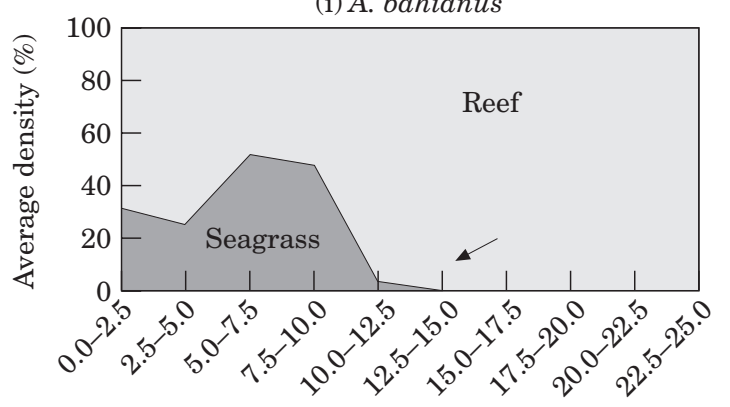

Size-classes $(\mathrm{cm})$ (b) H. sciurus

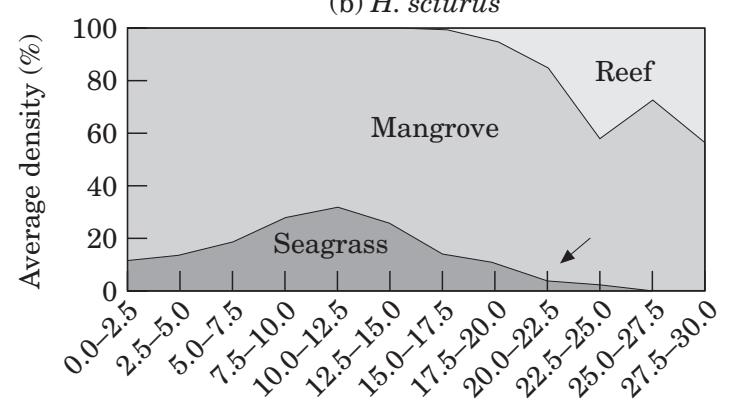

(d) Scarus taeniopterus
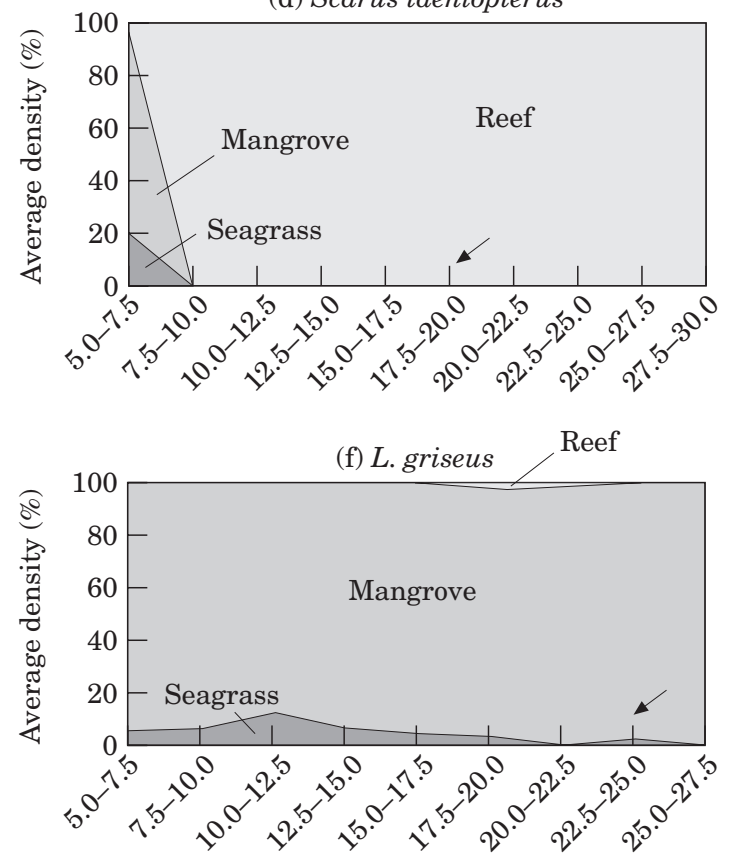

(h) Ocyurus chrysurus

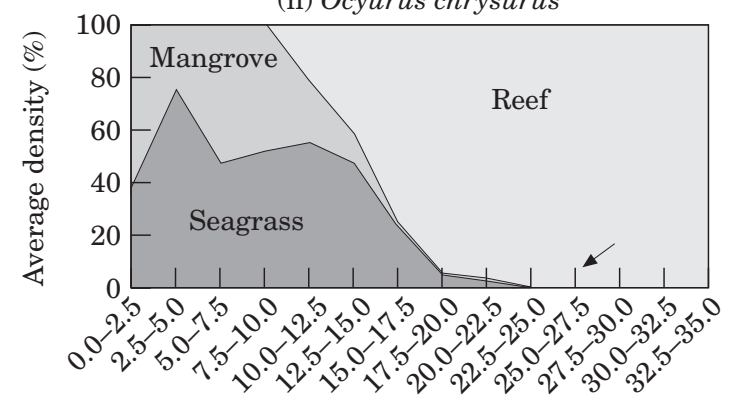

Size-classes $(\mathrm{cm})$ 
TABLE 3. Analysis of variance of sizes among sites within bay habitats. Bold print represents $P$-values smaller than $0 \cdot 05$. ANOVA could not be applied to $A$. bahianus and $S$. taeniopterus. Significant $P$-values indicate that variance of sizes of fishes is not homogeneously distributed over sites within that habitat

\begin{tabular}{lcc}
\hline & Mangrove & Seagrass \\
\hline Acanthurus bahianus & - & $0 \cdot 44$ \\
Acanthurus chirurgus & $0 \cdot 20$ & $0 \cdot 16$ \\
Haemulon flavolineatum & $\mathbf{0 \cdot 0 0}$ & $\mathbf{0 \cdot 0 0}$ \\
Haemulon sciurus & $0 \cdot 20$ & $\mathbf{0 \cdot 0 0}$ \\
Lutjanus apodus & $0 \cdot 15$ & $0 \cdot 16$ \\
Lutjanus griseus & $0 \cdot 35$ & $0 \cdot 27$ \\
Ocyurus chrysurus & $0 \cdot 10$ & $\mathbf{0 \cdot 0 0}$ \\
Scarus iserti & $\mathbf{0} 00$ & $\mathbf{0 \cdot 0 0}$ \\
Scarus taeniopterus & - & $\mathbf{0 \cdot 0 0}$ \\
\hline
\end{tabular}

H. sciurus, Lutjanus apodus, Ocyurus chrysurus, Acanthurus chirurgus, and Scarus iserti) showed spatial distributions in which smallest individuals were only found in bay habitats. The largest individuals of Haemulon flavolineatum, Lutjanus apodus, Ocyurus chrysurus, and Scarus iserti were found only on the adjacent reef, while adults of Haemulon sciurus, and Acanthurus chirurgus were found both in reef habitats as well as in bay habitats (mangrove or seagrass). Average size of these six species was largest on the reef. The size at which these species become sexually mature (Robertson \& Warner, 1978; Munro, 1983; Munro pers. comm.) always corresponded to or was larger than the average size at which they were found on the coral reef. The results suggest a Postsettlement Life Cycle Migration (PLCM) pattern over a considerable distance, in which juveniles settle and grow up in alternative habitats such as seagrass beds and mangroves, after which the sub-adults migrate to reef habitats where they become sexually mature. That pattern is named Long Distance PLCM. Average size of Lutjanus griseus was smallest in seagrass beds, while average sizes in mangroves and on reefs were similar. The size at which Lutjanus griseus becomes sexually mature is about $25 \mathrm{~cm}$ (Starck, 1971; Claro, 1983), and individuals of this size have been observed in mangroves as well as on the reef. Since small juveniles of Lutjanus griseus were only observed in bay habitats, and spawning occurs on the reef or shelf edge (Claro, 1983), it is assumed that it is a 'nursery species' as well, and that it migrates according to the above mentioned Long Distance PLCM pattern. This distribution pattern fits the observed size-distribution by other authors well (e.g. Parrish, 1989 and references therein; Rutherford et al., 1989; Appeldoorn et al., 1997), with larger individuals found progressively off-shore.

Three species, Haemulon flavolineatum, Ocyurus chrysurus and Scarus iserti, showed similar sizefrequency distribution patterns with three spatially separated groups that were statistically different: small juveniles in the mouth of the bay, larger individuals in seagrass beds and mangroves located deeper into the bay and (sub-) adults on the reef. This spatial distribution suggests a Life Cycle Migration that involves more than one direction of migration, and is hence termed Stepwise PLCM. Post-larvae of these species settle in the mouth of the bay, after which they migrate deeper into the bay to grow up to a size large enough to migrate to and dwell on the reef. Most migrants into coastal regions come from the open sea (Blaber, 1997). These are in-out migrations: juveniles or adults or both migrate into an estuarine or coastal area for a certain period, after which they return to the open sea or coral reef. De Sylva (1963) describes a distribution pattern of Sphyraena barracuda that is coherent to the Stepwise PLCM patterns that were found in our study. Post-larvae and juveniles of this piscivore move from coastal shallows to reed beds or mangroves, followed by a migration to open sea.

Juveniles of Scarus taeniopterus and Acanthurus bahianus were only found in the mouth of the bay and on the reef. Small juveniles of Acanthurus bahianus were only observed in seagrass beds in the mouth of the bay and in the reef flats, while adults occurred almost exclusively on the reef. These two species display a type of Short Distance PLCM in which larvae partly settle in the mouth of the bay and partly in the reef flats, to reach a size at which they migrate to deeper reef habitats.

Interestingly, some congeneric species appeared to display different directions of migration at similar sizes. Scarids of similar sizes are found mixed in the mouth of the bay, but one species then migrates to reef habitats (Scarus taeniopterus), and the other migrates deeper into the bay and only dwells on the reef at larger sizes (Scarus iserti). Leaving unidentifiable scarids smaller than $5 \mathrm{~cm}$ out of the data sets 

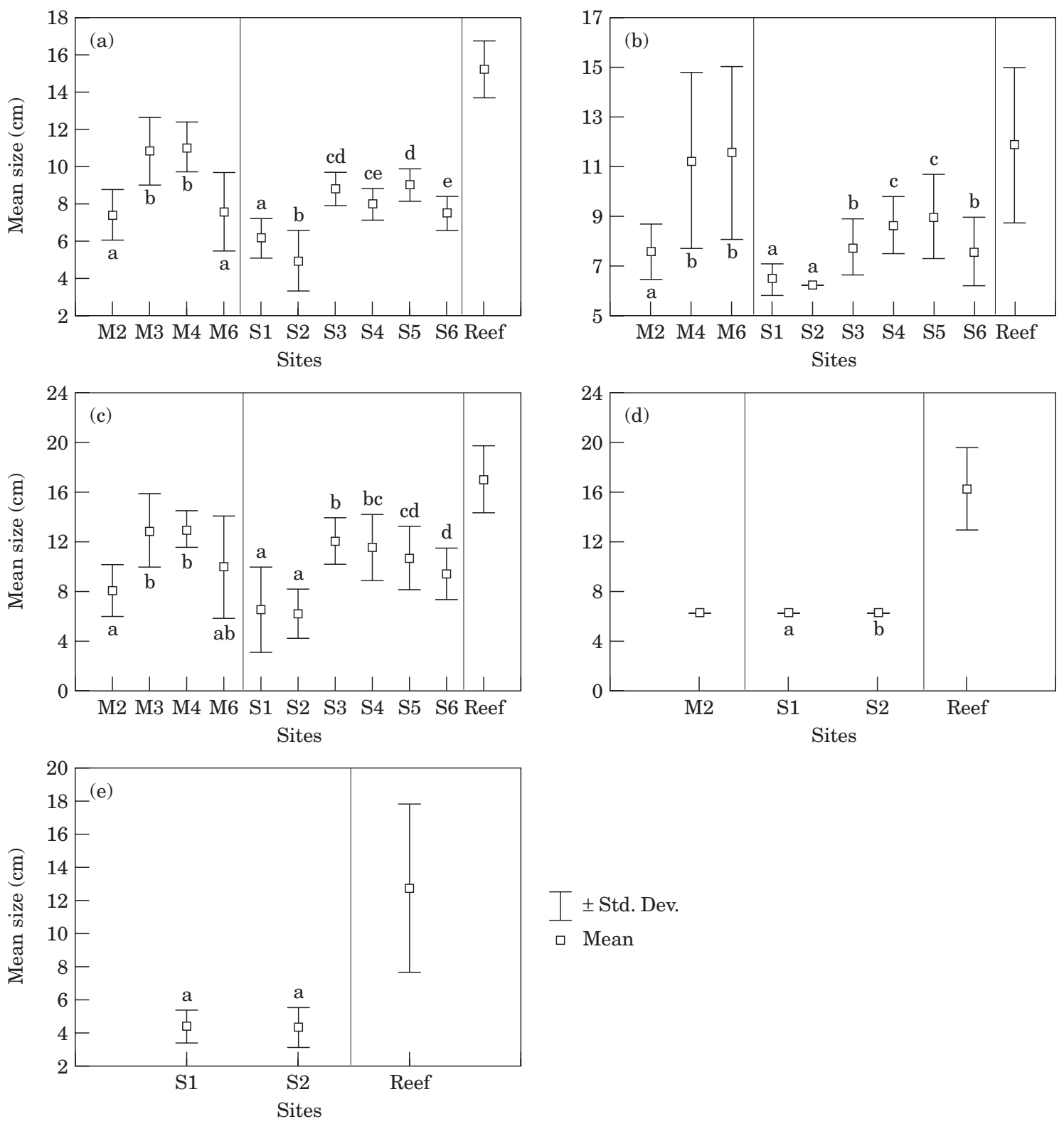

FIGURE 4. Mean and standard deviation of size-distribution of Haemulon flavolineatum (a), Scarus iserti (b), Ocyurus chrysurus (c) Scarus taeniopterus (d) and Acanthurus bahianus (e) at each site. Within each habitat (indicated with ' $S$ ', ' M ', or ' Reef ', for seagrass, mangrove and reef habitats, respectively), statistically significant differences among sites (Tukey HSD) are presented by letters only when the species was found in that habitat at more than one site. Different letters mean that the averages of the sites are statistically different.

did not affect conclusions regarding the spatial migration patterns of these species, since this sizeclass was almost exclusively found in the mouth of the bay. Apparently, both scarids settle in seagrass beds and mangroves located in the mouth of the bay, after which each migrates in an opposite direction. The same difference is observed when comparing the migration patterns of Acanthurus chirurgus and $A$. bahianus. Of Acanthurus bahianus it is known that behavioural interactions are size-related and can affect distribution, abundance and early post-settlement persistence of settlers (Risk, 1998), while postsettlement habitat selection is important in creating spatial patterns of recruitment (Sponaugle \& Cowen, 1996). This means that competitive congeneric species can alleviate competition on the reef by temporary spatial separation.

Possible explanations for different spatial sizefrequency distributions of post-settlement fishes involve variability in mortality rates, growth, 


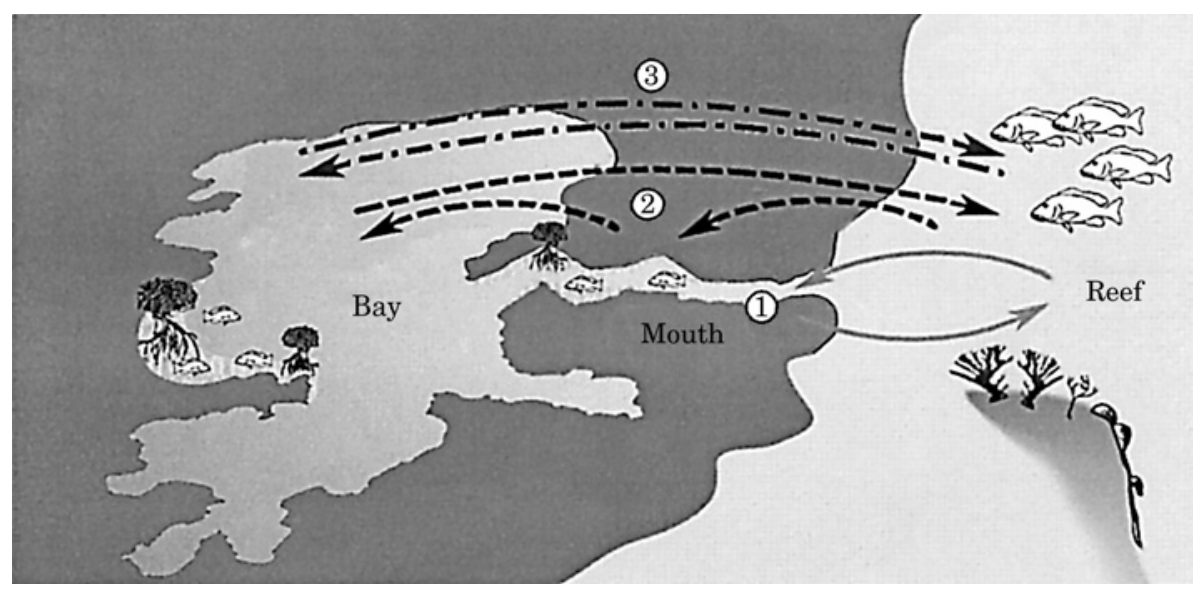

FIGURE 5. Three types of migration among nurseries and the coral reef. Route 1 depicts the Short Distance PLCM, route 2 Stepwise PLCM, and route 3 Long Distance PLCM (explanation see text).

settlement patterns and migration patterns. Since the abundance of predators is much lower in the bay than on the reef as is generally the case (Shulman, 1985; Parrish, 1989), differences in mortality rates may explain the high abundance of juveniles in bay habitats and the reduced numbers on the coral reef. In fact, reduced mortality among juveniles in nursery habitats is often ascribed to reduced predator abundance or efficiency (e.g. Heck \& Crowder, 1991; Robertson \& Blaber, 1992). This, however, cannot explain the lower number of (sub-)adults in mangrove and seagrass habitats or the low numbers of the smallest juveniles in the habitats that are located deep in the bay. Also, abundance and availability of food items (such as benthic and planktonic invertebrates, epifauna and epiphytes) is much higher in the bay habitats of Spanish Water Bay than on the nearby coral reef (Cocheret de la Morinière et al., unpublished), which could not result in lower growth rates of fishes in the bay. Variability in growth rate is therefore another unlikely explanatory factor for the fact that the largest individuals of nursery species are usually found on the coral reef. The spawning seasons of the selected species are largely during the study period (Munro et al., 1973), and regular settlement (no major peaks) of postlarvae was observed for most of the species during the study. Considering all these processes, migration from nursery ground to coral reef habitat seems a logical explanation for the spatial distribution of size-classes of these fish species, and migratory patterns can be inferred. The stability of such patterns and validity of actual migrations must be tested in further studies.

\section{Conclusions}

Taking day-to-day variations in fish density and sizefrequency into account over a five-month period, spatial patterns emerge for the selected fish species. Of some species, all size-classes that occurred in bay habitats appeared to prefer mangroves as daytime resting sites, while others were only found in seagrass beds. Other species utilized and preferred mangroves and seagrass beds at different sizes, and preference for mangroves of some species increased with increasing size-class.

The size-frequency distribution patterns of Haemulon flavolineatum, $H$. sciurus, Acanthurus chirurgus, Lutjanus apodus, Scarus iserti, and Ocyurus chrysurus in mangroves and seagrass beds and on the reef suggest a size-range for each species over which the juveniles start migrating to the coral reef (Figure 3). In the case of Scarus taeniopterus this migration from nursery habitat to coral reef appears to take place rather abruptly, while individuals of Acanthurus bahianus may migrate to reef habitats at all sizes.

Haemulon sciurus, Lutjanus apodus, L. griseus, and Acanthurus chirurgus display Long Distance PLCM; Haemulon flavolineatum, Ocyurus chrysurus and Scarus iserti use Stepwise PLCM; Scarus taeniopterus and Acanthurus bahianus are retained within a small distance from the reef (Short Distance PLCM). These different migration patterns are depicted in Figure 5. The fact that some species carry out specific directional migrations and congeners may migrate to different areas raises questions concerning the mechanisms that trigger these migrational options, 
and their ecological or evolutionary meaning. This also encourages scientists to view the 'nursery question' not only from the point of view of benevolence of nursery areas, but also to elucidate why a species shows a particular migration pattern or why it does not.

\section{Acknowledgements}

We would like to thank all personnel of the Carmabi Foundation, where the research was carried out. The research was funded by the Netherlands Foundation for the Advancement of Tropical Research (WOTRO). The Stichting Nijmeegs Universiteitsfonds (SNUF) funded B. J. A. Pollux. Furthermore, we thank E. Kardinaal for supplying us with a map of the Spanish Water Bay and the Winkel family for the use of their pier. Finally, we would like to thank Blu Forman for her help with the graph on migration patterns, and P. H. Nienhuis for useful comments on the manuscript.

\section{References}

Appeldoorn, R. S., Recksiek, C. W., Hill, R. L., Pagan, F. E. \& Dennis, G. D. 1997 Marine protected areas and reef fish movements: the role of habitat in controlling ontogenetic migration. Proceedings of the 8th International Coral Reef Symposium 2, 1917-1922.

Baelde, P. 1990 Differences in the structures of fish assemblages in Thalassia testudinum beds in Guadeloupe, French West Indies, and their ecological significance. Marine Biology 105, 163-173.

Bak, R. P. M. 1975 Ecological aspects of the distribution of reef corals in the Netherlands Antilles. Bijdragen tot de Dierkunde 45, 181-190.

Birkeland, C. 1985 Ecological interactions between tropical coastal ecosystems. UNEP Regional Seas Reports and Studies 73, 1-26.

Blaber, S. J. M., Brewer, D. T. \& Salini, J. P. 1989 Species composition and biomasses of fishes in different habitats of a tropical northern Australian estuary: their occurrence in the adjoining sea and estuarine dependence. Estuarine, Coastal and Shelf Science 29, 509-531.

Blaber, S. J. M. (ed.) 1997 Fish and Fisheries of Tropical Estuaries, Volume 22. Chapman \& Hall, London, 353 pp.

Blaber, S. J. M. \& Blaber, T. G. 1980 Factors affecting the distribution of juvenile estuarine and inshore fish. Fournal of Fish Biology 17, 143-162.

Carr, W. E. S. \& Adams, C. A. 1973 Food habits of juvenile marine fishes occupying seagrass beds in the estuarine zone near Crystal River, Florida. Transactions of the American Fisheries Society 102, 511-540.

Claro, R. 1983 Ecologia y cicle de vida del caballerote, Lutjanus griseus (Linnaeus), en la platforma cubana. I. Identidad, distribucion y habitat, nutricion y reproduccion. Reportajes $y$ Investigaciones del Instituto por Oceanologia de la Academia de Sciencia de Cuba 7, 1-30.

De Haan, D. \& Zaneveld, J. S. 1959 Some notes on tides in Annabaai harbour, Curaçao, Netherlands Antilles. Bulletin of Marine Science of the Gulf and Caribbean 9, 224-236.

De Sylva, D. P. 1963 Systematics and life-history of the great barracuda Sphyraena barracuda. Studies in Tropical Oceanography $1,179 \mathrm{pp}$
Heck, K. L. \& Crowder, L. B. 1991 Habitat structure and predatorprey interactions in vegetated aquatic ecosystems. In Habitat Structure: The Physical Arrangements of Objects in Space (Bell, S. S., McCoy, E. D. \& Mushinsky, E. R., eds). Chapman and Hall, London, pp. 281-299.

Humann, P. 1996 Reef Fish Identification, 2nd edition. Florida Caribbean Bahamas. New World Publications Inc., Jacksonville, USA, 396 pp.

Kuenen, M. M. C. E. \& Debrot, A. O. 1995 A quantitative study of the seagrass and algal meadows of the Spaanse Water, Curaçao, The Netherlands Antilles. Aquatic Botany 51, 291-310.

Laegdsgaard, P. \& Johnson, C. 2001 Why do juvenile fish utilise mangrove habitats? Fournal of Experimental Marine Biology and Ecology 257, 229-253.

Munro, J. L., Gaut, V. C., Thompson, R. \& Reeson, P. H. 1973 The spawning seasons of Caribbean reef fishes. Fournal of Fish Biology 5, 69-84.

Munro, J. L. (ed.) 1983 Caribbean Coral Reef Fishery Resources, 2nd edition. ICLARM, Philippines, $276 \mathrm{pp}$.

Nagelkerken, I., Dorenbosch, M., Verberk, W. C. E. P., Cocheret de la Morinière, E. \& van der Velde, G. $2000 a$ Importance of shallow-water biotopes of a Caribbean bay for juvenile coral reef fishes: patterns in biotope association, community structure and spatial distribution. Marine Ecology Progress Series 202, 175192.

Nagelkerken, I., Dorenbosch, M., Verberk, W. C. E. P., Cocheret de la Morinière, E. \& van der Velde, G. $2000 b$ Day-night shifts of fishes between shallow-water biotopes of a Caribbean bay, with emphasis on the nocturnal feeding of Haemulidae and Lutjanidae. Marine Ecology Progress Series 194, 55-64.

Nagelkerken, I., van der Velde, G., Gorissen, M. W., Meijer, G. J., van 't Hoff, T. \& den Hartog, C. 2000c Importance of mangroves, seagrass beds and the shallow coral reef as a nursery for important coral reef fishes, using a visual census technique. Estuarine, Coastal and Shelf Science 51, 31-44.

Nagelkerken, I., Kleijnen, S., Klop, T., van den Brand, R. A. C. J., Cocheret de la Morinière, E. \& van der Velde, G. 2001 Dependence of Caribbean reef fishes on mangroves and seagrass beds as nursery habitats: a comparison of fish faunas between bays with and without mangroves and seagrass beds. Marine Ecology Progress Series 214, 225-235.

Odum, W. E. \& Heald, E. J. 1972 Trophic analyses of an estuarine mangrove community. Bulletin of Marine Science 22, 671-738.

Ogden, J. C. \& Ehrlich, P. R. 1977 The behaviour of heterotypic resting schools of juvenile grunts (Pomadasyidae). Marine Biology 42, 273-280

Ogden, J. C. \& Gladfelter, E. H. 1983 Coral reefs, seagrass beds, and mangroves: their interactions in the coastal zones of the Caribbean. UNESCO Reports in Marine Science 23, $133 \mathrm{pp}$.

Ogden, J. C. \& Zieman, J. C. 1977 Ecological aspects of coral reef-seagrass bed contacts in the Caribbean. Proceedings of the $3 r d$ International Coral Reef Symposium 1, 377-382.

Parrish, J. D. 1989 Fish communities of interacting shallow-water habitats in tropical oceanic regions. Marine Ecology Progress Series 58, 143-160

Pollard, D. A. 1984 A review of ecological studies on seagrass-fish communities, with particular reference to recent studies in Australia. Aquatic Botany 18, 3-42.

Risk, A. 1998 The effects of interactions with reef residents on the settlement and subsequent persistence of ocean surgeonfish, Acanthurus bahianus. Environmental Biology of Fishes 51, 377-389.

Robertson, A. I. \& Duke, N. C. 1987 Mangroves as nursery sites: comparisons of the abundance and species composition of fish and crustaceans in mangroves and other nearshore habitats in tropical Australia. Marine Biology 96, 193-205.

Robertson, A. I. \& Blaber, S. J. M. 1992 Plankton, epibenthos and fish communities. In Tropical Mangrove Ecosystems (Robertson, A. I. \& Alongi, D. M., eds). Coastal and Estuarine Studies No. $41,173-224$. 
Robertson, D. R. \& Warner, R. R. 1978 Sexual patterns in the labroid fishes of the Western Caribbean, II: The parrotfishes (Scaridae). In Smithsonian Contributions to Zoology (Robertson, D. R. \& Warner, R. R., eds). Smithsonian Institute, Washington, DC, No. 255, 635 pp.

Rooker, J. R. \& Dennis, G. D. 1991 Diel, lunar and seasonal changes in a mangrove fish assemblage off southwestern Puerto Rico. Bulletin of Marine Science 49, 684-698.

Rutherford, E. S., Schmidt, T. W. \& Tilman, J. T. 1989 Early life history of spotted sea trout (Cynoscion nebulosus) and gray snapper (Lutjanus griseus) in Florida Bay, Everglades National Park, Florida. Bulletin of Marine Science 44, 49-64.

Sedberry, G. R. \& Carter, J. 1993 The fish community of a shallow tropical lagoon in Belize, Central America. Estuaries 16, 198-215.

Shulman, M. J. 1985 Recruitment of coral reef fishes: efects of distribution of predators and shelter. Ecology 66, 1056-1066.

Sokal, R. R. \& Rohlf, F. J. 1995 Biometry, 3rd edition. WH Freeman and Company, New York, 887 pp.
Sponaugle, S. \& Cowen, R. K. 1996 Larval supply and patterns of recruitment for two Caribbean reef fishes, Stegastus partitus and Acanthurus bahianus. Marine and Freshwater Research 47, 433447.

Starck, W. A. \& Schroeder, R. E. 1971 Investigations on the gray snapper Lutjanus griseus. Studies in Tropical Oceanography 10, $224 \mathrm{pp}$.

Thayer, G. W., Colby, D. R. \& Hettler, W. F. Jr 1987 Utilization of the red mangrove prop root habitat by fishes in south Florida. Marine Ecology Progress Series 35, 25-38.

Weinstein, M. P. \& Heck, K. L. Jr 1979 Ichthyofauna of seagrass meadows along the Caribbean coast of Panamá and in the gulf of Mexico: composition, structure and community ecology. Marine Biology 50, 97-107.

Yáñez-Arancibia, A., Lara-Dominguez, A. L., Rojas-Galaviz, J. L., Sánchez-Gil, P., Day, J. W. \& Madden, C. J. 1988 Seasonal biomass and diversity of estuarine fishes coupled with tropical habitat heterogeneity (southern Gulf of Mexico). Fournal of Fish Biology 33 (Suppl A), 191-200. 